\title{
CYTOKINE AND IMMUNOGLOBULIN SPECTRA OF TISSUE EXTRACTS FROM TONSILS OF CHILDREN WITH HYPERTROPHY AND CHRONIC TONSILLITIS
}

DOI: 10.36740/WLek202001130

\author{
Oleksandr Bredun', Marina Tymchenko², Inna Faraon², Oleg Melnikov ${ }^{2}$ \\ 'SHUPYK NATIONAL MEDICAL ACADEMY OF POSTGRADUATE EDUCATION, KYIV, UKRAINE \\ 20. KOLOMIYCHENKO OTOLARYNGOLOGY INSTITUTE, KYIV, UKRAINE
}

\begin{abstract}
The aim: To compare the content of $a$ and $\gamma$-interferons, interleukins $1 \beta, 4,10, \lg A, \operatorname{lgG}$, as well as the level of the general forms of immune complexes in tissue extracts from tonsils of children with hypertrophy and chronic tonsillitis.

Materials and methods: We studied tonsils of 25 children aged 5-12 years with hypertrophy of palatine tonsils (HPT) and with chronic tonsillitis (CT). The content of a and $\gamma$ - interferons, interleukins $1 \beta, 4,10, \lg A$, IgG in tonsil extract was determined by immunofluorescence assay. Immune complexes were determined using sedimentary test (3.75\% solution of polyethylene glycol).

Results: In tissue extracts from tonsils with CT, there is a predominance of inflammation factors, potential sensitization, and the development of immunopathological reactions. The presence of inflammation is indicated by elevated levels of interleukin-1 $\beta$, immunoglobulin $\mathrm{G}$. High levels of interleukin- 4 may indicate that both HPT and CT have a tendency to increase sensitization to microbial and other antigens.

Conclusion: The results indicate a significant difference in the qualitative and quantitative state of inflammation factors and allergy in case of HPT and CT. In tonsils with CT, there predominate both simple and allergic inflammations, as well as immunopathological reactions.
\end{abstract}

KEY WORDS: Hypertrophy of palatine tonsils, chronic tonsillitis, inflammation factors, allergy

Wiad Lek. 2020;73(1):156-160

\section{INTRODUCTION}

Currently it is clinically proven and experimentally grounded that the structures of Waldeyer's ring have a great impact on the local humoral immunity, both in the nasopharynx and oropharynx, where the primary protection components are secretory immunoglobulin $\mathrm{A}$, interferons and innate immune humoral factors $[1,2,3,4]$. At the same time, it should be noted that the opinion of various researchers regarding the content of these humoral factors in case of chronic tonsillitis and hypertrophy of palatine tonsils significantly differ. Some authors find with little to no difference in the content of various immunity factors in the tonsillar tissue between hypertrophy and tonsillitis with the exception of tissue morphology [5] and the presence of an allergic background, a significant reactivity change in case of hypertrophy [6]. Other authors believe that hypertrophy of palatine tonsils and tonsillitis significantly differ in quantitative characteristics in the content of factors of nonspecific immunity and inflammation $[7,3]$. Therefore, it seems appropriate to further study the humoral protection mechanisms that are in the structures of the pharyngeal lymphoid tissue ring. Thus, the aim of the study is to compare the content of $\alpha$ and $\gamma$-interferons, interleukins $1 \beta, 4,10, \operatorname{Ig} A, \operatorname{IgG}$, as well as the level of the general forms of immune complexes in tissue extracts from tonsils of children with hypertrophy and chronic tonsillitis.

\section{THE AIM}

The aim of the study is to compare the content of $\alpha$ and $\gamma$-interferons, interleukins $1 \beta, 4,10, \operatorname{Ig} \mathrm{A}, \mathrm{IgG}$, as well as the level of the general forms of immune complexes in tissue extracts from tonsils of children with hypertrophy and chronic tonsillitis.

\section{MATERIALS AND METHODS}

We studied the content of these factors in extracts from tonsils of 2 groups of children aged 5-12 years. Group 1 involved children with hypertrophy of palatine tonsils (HPT) of grade 2-3 (11 persons). Group 2 consisted of children with chronic tonsillitis (CT) (14 persons).

The tissue extracts from tonsils were prepared in a $0.85 \% \mathrm{NaCl}$ solution at a ratio of $1: 5$. The technique of preparation of extracts met the recommendations of [8]. Statistical processing was carried out using Mann-Whitney U-test (Wilcoxon) [9]. Immune complexes were determined using sedimentary test with a $3.75 \%$ solution of polyethylene glycol according to the recommendations of Nasonov [10]. Determination of interferons and interleukins in extracts was carried out using the Cytokin LLC reagent kits (RF) and the Lab line (Austria) enzyme immunoassay analyzer, and IgA and IgG monomeric 

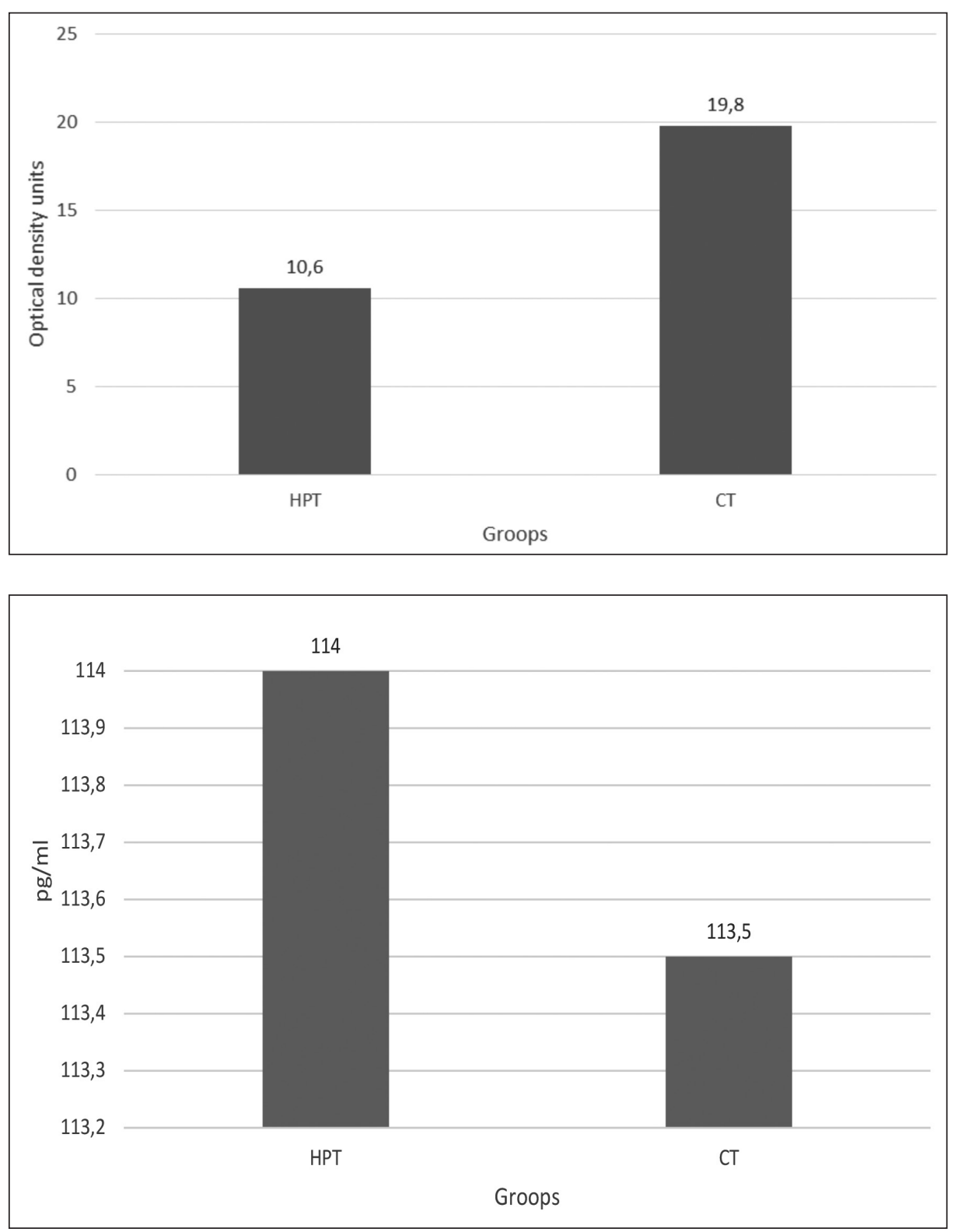

Fig. 1. The content of immune complexes in extracts from tonsils in case of HPT and CT.
Fig. 2. The content of interleukin-4 in extracts from tonsils in case of HPT and CT. form determination by immunoenzyme method (Hema reagents, $\mathrm{RF}$ ).

In carrying out the research, the principles of bioethics and the legal requirements and requirements for conducting biomedical research were respected, namely: the Helsinki Declaration (2000), the Constitution (1996) and the Civil Code of Ukraine (2006), the Fundamentals of Ukrainian Health Law (1992), Guidelines for clinical investigations of the Ministry of Health of Ukraine No. 42-7.0: 2005 "Medicines. Appropriate clinical practice "(2005), Order of the Ministry of Health of Ukraine No. 66" On Approval of the Procedure for Conducting Clinical Trials of Medicinal Products and Examination of Materials for Clinical Trials and Model Regulations on the Ethics Commission "(2006), Law of Ukraine No. 3447-IV” On the Protection of Animals from ill-treatment "(2006), which is confirmed by the corresponding conclusion of the Ethical Committee of Shupyk National Medical Academy of Postgraduate Education, Kyiv, Ukraine (2015).

\section{RESULTS}

Data on the content of immune complexes are presented in Figure 1, which shows that the number of immune complexes in tonsillar tissues is twice lower in case of hypertrophy than in case of chronic tonsillitis.

Data on the content of interferons in extracts from tonsils in case of hypertrophy and chronic tonsillitis are presented in Table I.

Data on the content of interleukin- 4 are presented in Figure 2, and the ratio of $\gamma$-interferon / interleukin-4 in Figure 3.

From the data in Figure 2 it follows that the levels of this cytokine in case of hypertrophy of palatine tonsils and chronic tonsillitis are about the same, and the ratio of $\gamma$-IFN and IL-4 is less in case of chronic tonsillitis (0.93) than in case of hypertrophy of palatine tonsils (1.21) (Figure 3). It indicates a greater tendency of the tonsillar tissue to form an immunopathological pro-allergic response in case of chronic tonsillitis [11]. 
Table I. The content of $a$ and $\gamma$ interferons in tissue extracts in case of HPT and CT.

\begin{tabular}{ccc}
\hline Groups & a-IFN, $\mathrm{pg} / \mathrm{ml}$ & v-IFN, pg/ml \\
\hline HPT $(\mathrm{n}=11)$ & $41.0(34-50)^{*}$ & $137.8(91-190)^{* *}$ \\
\hline $\mathrm{CT}(\mathrm{n}=14)$ & $50.6(38-84)^{*}$ & $106.0(59-140)^{* * *}$ \\
\hline
\end{tabular}

Note: ${ }^{*}-p>0.05,{ }^{* *}-p=0.065$.
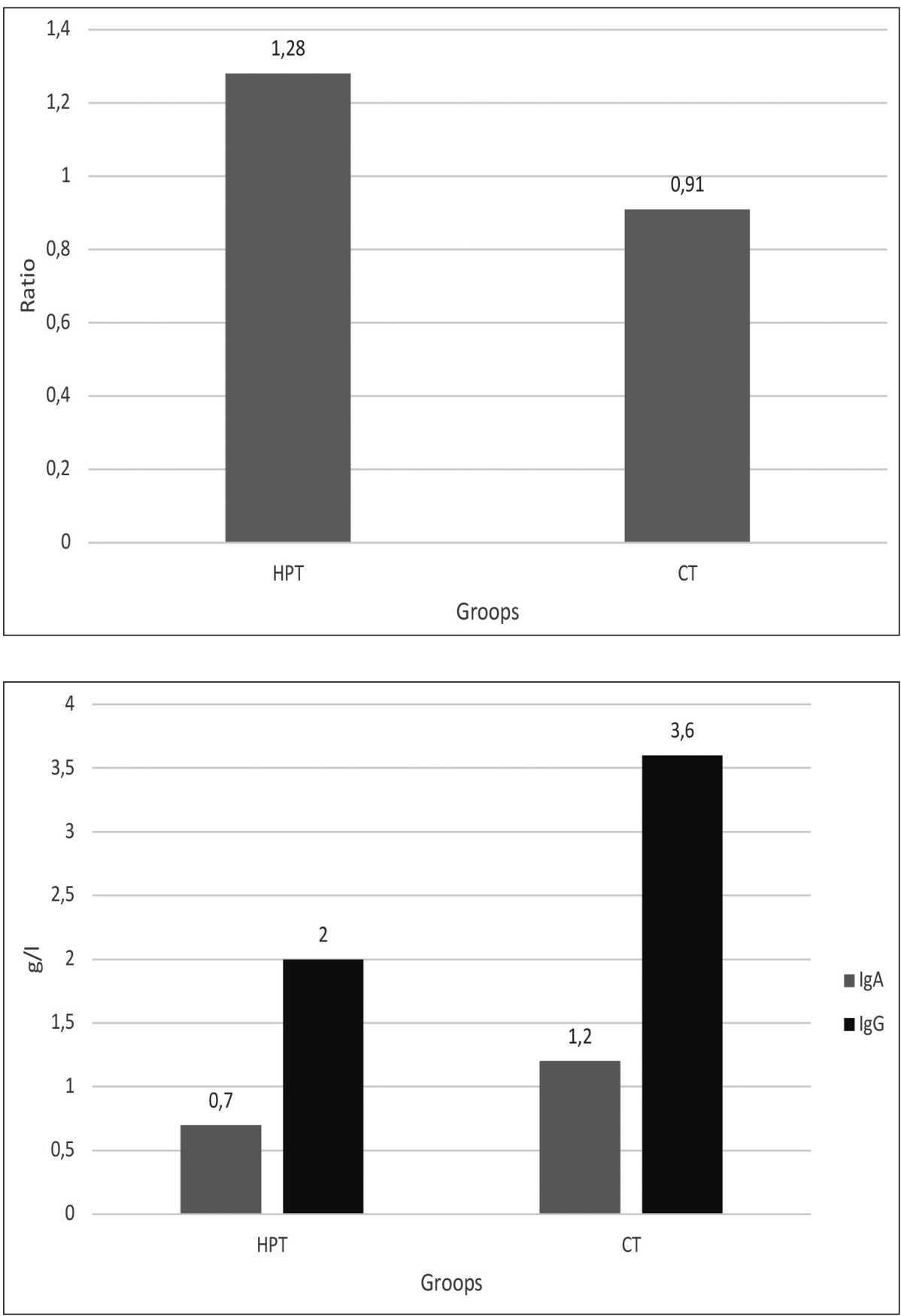

Fig. 3. The ratio of $\gamma$-interferon/interleukin-4 content in extracts from tonsils in case of HPT and CT.
Fig. 4. IgA and $\lg G$ levels $(g / l)$ in extracts from tonsils in case of hypertrophy and chronic tonsillitis.
From the data in Table II it follows that significant differences between the groups were only in relation to pro-inflammatory IL- $1 \beta$, the content of which is significantly higher in case of chronic tonsillitis, which according to early research [12] directly indicates the presence of an inflammatory process in the tonsils of children.
IgA and IgG levels in extracts are presented in Figure 4. It can be seen that immunoglobulins $\mathrm{A}$ are contained in extracts from HPT and CT at about the same concentration with an unreliable prevalence in extracts from CT (HPT $0.7 \mathrm{~g} / \mathrm{l}$ and CT $1.2 \mathrm{~g} / \mathrm{l})$. IgG content was significantly higher in tissue extracts of patients with CT $(2.0 \mathrm{~g} / \mathrm{l}$ in case of HPT and $3.6 \mathrm{~g} / \mathrm{l}$ in case of $\mathrm{CT}$ ). 
Table II. The content of interleukins $1 \beta$ and 10 in tissue extracts from tonsils in case of hypertrophy of palatine tonsils and chronic tonsillitis.

\begin{tabular}{ccc}
\hline Groups & IL-1 $\mathbf{\beta}, \mathbf{p g} / \mathbf{m l}$ & IL-10, pg/ml \\
\hline HPT $(n=11)$ & $136.0(102-184)^{*}$ & $12.5(9-20)^{* *}$ \\
\hline CT $(n=14)$ & $195.8(171-305)^{*}$ & $18.0(9-24)^{* *}$ \\
\hline
\end{tabular}

Note: ${ }^{*}-p<0.05,{ }^{* *}-p=0.1$.

\section{DISCUSSION}

Our fin dings indicate that in tissue extracts from tonsils with CT obtained ad mass, there is a predominance of inflammation factors and potential sensitization, as well as the development of immunopathological reactions. The presence of inflammation is indicated by elevated levels of interleukin- $1 \beta$, immunoglobulin $G[13,3]$. High levels of interleukin- 4 may indicate that both HPT and CT have a tendency to increase the activity of Th-2 cells, which means that hypertrophy and chronic tonsillitis in children can appear both in the form of sensitization to microbial and other antigens, and in the form of allergic inflammation, as evidenced in the study of cytokine levels in case of other inflammatory processes [11]. Based on the data presented and also taking into account the materials on chronic tonsillitis $[2,3,4,14]$ it may be considered appropriate to set the diagnosis of chronic tonsillitis, as recommended in the ICD-11 project.

\section{CONCLUSIONS}

1. The number of immune complexes in chronic tonsillitis is significantly $(\mathrm{p}<0.05) 1.86$ times their number in tonsil hypertrophy.

2. The ratio of $\gamma$-IFN and IL-4 is less in case of chronic tonsillitis (0.93) than in case of hypertrophy of palatine tonsils (1.21).

3 . The content of pro-inflammatory IL- $1 \beta$ is significantly higher $(\mathrm{p}<0.05)$ in case of chronic tonsillitis.

4. IgG content was significantly 1.8 times higher $(p<0.05)$ in the tissue extracts of the tonsils of patients with CT than with HPT.

5. The content of $\alpha$-IFN, $\gamma$-IFN and IgA of tonsils extracts with hypertrophy and chronic tonsillitis have no significant differences.

\section{REFERENCES}

1. Melnikov 0 , Zabolotny D. Diagnostica immunodeficitov pri patologii slizistoy obolochki na osnove opredeleniya immunoglobulinov v secretah (concepciya). [Diagnosis of immunodeficiencies in pathology of the mucosa based on the definition of immunoglobulins in biological fluid (concept)]. Kiev: Inst. Otolaringol. 2003, 30 p (in Russian).

2. Melnykov 0, Zabolotnaya D. Sovremenny podhody konservativnoy terapii chronicheskogo tonsillita [Modern approaches to the conservative treatment of chronic tonsillitis]. Kiev. «Vistka» Ltd. 2012, $80 \mathrm{p}$ (in Russian).

3. Melnikov 0, Zabolotny D, Kischuk V, Bredun 0, Ryilska 0. Immunologiya chronicheskogo tonzillita. [Immunology of Chronic Tonsillitis]. Kiev: «LOGOS». 2017, 192 p (in Russian).
4. Brandtzaeg P. Immune Function of Nasohharyngeal Lymphoid Tissue. Recent Advances in Tonsils \& Mucosal Barriers of the Upper Airways. JRL. 2010; 72:18-22.

5. Sabau B, Boldea C, Moseanu S, et al. An anatomomorphological features of chronic tonsillar diseases. 6 th International symposium on tonsils \& mucosal barriers of the upper airways. -Siena (Italy). 2006, abas. A2.

6. Layko A. Hipertrofiya limfoyidnoyi tkanyny hlotky. In: Zabolotny D, Kosakovsky A, Bereznyuk V et al. [Hypertrophy of the lymphatic tissue of the pharynx]. Kiev: «LOGOS». 2009, 175 p (in Ukranian).

7. Khotsianovskiy K. Taktika likuvanya ditey z hypertrofiyeyu pidnebinnyh mygdalykiv. [Tactics of treatment of children with hypertrophy of palatine tonsils]. Autoref. Diss. Cand. of Medicine Science. 14.01.19. Kiev. Institute of Otolaryngology, Academy of Sciences of the Ukraine. 2002, 18 p. (in Ukranian).

8. Melnykov 0. Immunological aspects of the genesis of chronic tonsillitis and regulation of the functional activity of the palatine tonsils. Diss. Doctor of Medicine Science. 14.00.16. Kiev. Institute of Physiology, Academy of Sciences of the Ukrainian SSR. 1981, 294 p. (in Russian).

9. Gubler Ye. Matematicheskiye metody analiza i raspoznavaniya patologicheskikh protsessov. [Mathematical methods of analysis and recognition of pathological processes]. Leningrad: Medicina. 1978, 295 p (in Russian).

10. Nasonov Y. Metodologicheskie aspekty opredeleniya cirkuliruyuschih immunnih kompleksov $s$ ispolsovaniyem polyetilenglycolya. [Methodological aspects of the determination of circulating immune complexes using polyethyleneglycol]. Ther. Arch. 1987; 4:38-45. (in Russian).

11. Krivitskaya V, Somnina A, Sukholveckaya V. Immunnopatologicheskiy allergicheskiy Th-2 typ protivovirusnogo gumoralnogo immuniteta u detey s respiratorno-sincitialnoy virusnoy infekciey. [Immunopathological allergic Th-2 type of antiviral humoral immunity in children with respiratory syncytial viral infection]. Cytokines and inflammation. 2004; 3: 34-37 (in Russian).

12. Demianov A, Kotov A, Symbirtsev A. Diagnosticheskaya cennost issledovaniya urovney cytokinov v klinicheskoy praktike. [Diagnostic value of cytokine study in clinical practice]. Cytokines and inflammation. 2003; 2(3): 20-36 (in Russian).

13. Kovalchuk L, Gankovskaya L, Meshkova R. Klinicheskaya immunologiya i allergologiya s osnovami obshchey immunologii. [Clinical Immunology and Allergology with Fundamentals of General Immunology]. Moscow: GEOTARMedia. 2011, 640p (in Russian).

14. Windfuhr J, Toepfner N, Steffen G., et.al. Clinical practice guidline: Tonsillitis 1. Diagnostics and nonsurgical management. Eur Arch Otorhinolaryngol. 2016; b 273: 974-989.

The research was carried out within the framework of the research work of the Department of Pediatric Otorhinolaryngology of the Shupyk National Medical Academy of 
Postgraduate Education, Kyiv, Ukraine - "Diagnosis and treatment of diseases of ear, throat and nose in children" (State registration number 0113U002213).

\section{ORCID and contributionship:}

Oleksandr Bredun - 0000-0002-5013-7318 A,B,D

Marina Tymchenko - 0000-0002-2734-604X ${ }^{B, C}$

Inna Faraon - 0000-0003-1010-4308 ${ }^{B, C}$

Oleg Melnikov - 0000-0002-1261-8647 ${ }^{A, E, F}$

\section{Conflict of interest:}

The Authors declare no conflict of interest

\section{CORRESPONDING AUTHOR}

\section{Oleksandr Bredun}

Shupyk National Medical Academy of Postgraduate Education

9 Dorohozhytska Str., Kyiv, 04112, Ukraine

tel: +380505605852

e-mail: alexbredun@gmail.com

Received: 17.09 .2019

Accepted: 10.12.2019

A - Work concept and design, B - Data collection and analysis, C - Responsibility for statistical analysis,

$\mathbf{D}$-Writing the article, $\mathbf{E}$-Critical review, $\mathbf{F}$ - Final approval of the article 